\title{
Editorial: Transport in a low-carbon managed future
}

Tom Cherrett BSc, PhD, CMILT

Senior Lecturer, Transportation Research Group, University of Southampton, UK
Stephen Ison BA, MA, PhD, CMILT

Professor, Transport Studies Group, Loughborough University, UK
Of increasing interest is the extent to which transport systems and services will be gauged and potentially adopted according to their carbon intensity. With the global drive to reduce carbon dioxide emissions, the transport sector is seen as a key area where combinations of technology adoption and scheme buy-in, coupled with strategic behavioural change could help reduce our overall 'carbon footprint'. This is being increasingly recognised and demonstrated in recent UK government policy (DfT, 2009a, 2009b)

This themed issue of Transport investigates how the planning, design and management of transport systems is now being undertaken in an environment of a low-carbon managed future.

Mindell et al. (2011) set the scene by exploring the ways in which the low-carbon and health agendas complement each other, and discuss the way in which cross-disciplinary synergies between low-carbon approaches and health are important to both policy fields. They also explain that effective low-carbon policies must reduce the need to travel and promote modal shift but argue that making transport carbon dioxide-free will neither offset all health issues nor deliver all quality-of-life requirements.

The paper by Menichetti and van Vuren (2011) explores the general requirements and challenges associated with developing a modelling system to aid the planning and implementation of an integrated carbon dioxide-neutral transport system, using a case study city example. They identify the travel demand and supply characteristics to be considered and explain the specific modelling requirements compared with more conventional situations.

Ghumra et al. (2011) address the issue of how 'sustainable' transport projects can be accurately assessed so that carbon reduction benefits can be accurately quantified. Their research involves a detailed analysis of 24 transport-focussed Ceequal projects, with recommendations as to how the process can be further developed so as to benefit wider civil engineering projects. In a similar way, Fox et al. (2011) describe the carbon footprinting and assessment tools (carbon management system (CMS)) commissioned by Transport Scotland, and a series of case studies where the CMS has been used to report infrastructure project carbon dioxide emissions and improve design. Among other aspects, their research has addressed the need to examine carefully the wider transport implications of recycled content specifications as part of lower-carbon infrastructure solutions.

Two papers address the potential for behavioural change in transport use in order to bring about carbon reduction benefits. Parker et al. (2011) examine the extent, reach and coverage of current car sharing schemes in the Yorkshire and Humber region and explore the contribution that car sharing can play in reducing carbon dioxide emissions and improving access to services. The motivations and behaviours of people who integrate bicycle and rail use are explored by Sherwin et al. (2011), and the extent to which integration within the rail industry and other agencies related to cycle parking provision can reduce both carbon dioxide emissions and car dependence.

The final paper, by Wilford and Fraser (2011), sums up the current state of play with regard to how authorities in England are acting on climate change and monitoring emissions as part of the delivery of local and regional transport services, in preparation for the third round of local transport plans. The paper investigates the existing goals and public commitments signed up to, the transport policies and initiatives delivered, and the drivers, challenges and barriers that authorities are facing in tackling carbon dioxide emissions from transport. The authors also discuss the tools, guidance and methodologies currently in use to assess the carbon impact of transport policies; and the coverage, advantages and disadvantages of the monitoring and evaluation methodologies identified.

The papers in this themed issue provide a useful contribution to the low-carbon transport debate.

\section{REFERENCES}

DfT (Department for Transport) (2009a) Low Carbon Transport: A Greener Future. A Carbon Reduction Strategy for

Transport. DfT, London, UK. See http://www.officialdocuments.gov.uk/document/cm76/7682/7682.pdf (accessed 24/06/2011).

DfT (2009b) Delivering Sustainable Low Carbon Travel: An Essential Guide for Local Authorities. DfT, London, UK. See http://www2.dft.gov.uk/pgr/sustainable/guidelocalauth/pdf/ lowcarbontravel.pdf (accessed 24/06/2011).

Fox J, Bell D, Edmond G, Cummings P and Langstraat J (2011) A practical tool for low-carbon road design and construction. Proceedings of the Institution of Civil Engineers - Transport 164(3): 165-179.

Ghumra S, Glass J, Frost MW, Watkins M and Mundy J (2011) Materials and energy assessment in Ceequal transport projects. Proceedings of the Institution of Civil Engineers Transport 164(3): 153-164. 
Menichetti D and van Vuren T (2011) Modelling a low-carbon city. Proceedings of the Institution of Civil Engineers Transport 164(3): 141-152.

Mindell JS, Cohen JM, Watkins S and Tyler N (2011) Synergies between low-carbon and healthy transport policies.

Proceedings of the Institution of Civil Engineers - Transport 164(3): 127-139.

Parker J, Walker C and Johnson R (2011) What can we learn from car sharing experiences in the UK? Proceedings of the Institution of Civil Engineers - Transport 164(3): 181188.

Sherwin H, Parkhurst G, Robbins D and Walker I (2011) Practices and motivations of travellers making rail-cycle trips.

Proceedings of the Institution of Civil Engineers - Transport 164(3): 189-197.

Wilford F and Fraser S (2011) Local and regional climate change research. Proceedings of the Institution of Civil Engineers Transport 164(3): 199-206. 